DOI: $\underline{\text { https://doi.org/10.31933/jemsi.v3i2 }}$ Received: 25 September 2021, Revised: 5 November 2021, Publish: 6 Desember 2021

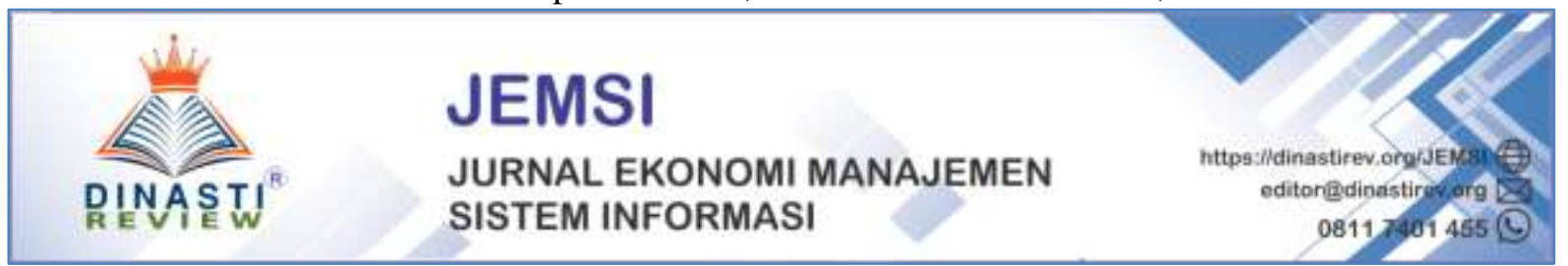

\title{
ARISAN UANG DALAM MENAMBAH KESEJAHTERAAN KELUARGA MENURUT PERSPEKTIF EKONOMI ISLAM (STUDI KASUS DI DESA PANDAN LAGAN KECAMATAN GERAGAI)
}

\author{
Ruwaidah Ruwaidah $^{1}$, M.Arif Musthofa ${ }^{2}$, Khusnul Yatima ${ }^{3}$ \\ ${ }^{1)}$ Sekolah Tinggi Ilmu Ekonomi Syari’ah Al-Mujaddid Tanjung Jabung Timur, \\ ruwaydahhida@gmail.com \\ ${ }^{2}$ Sekolah Tinggi Ilmu Ekonomi Syari’ah Al-Mujaddid Tanjung Jabung Timur, \\ Musthofaarif77@gmail.com \\ ${ }^{3)}$ Sekolah Tinggi Ilmu Ekonomi Syari’ah Al-Mujaddid Tanjung Jabung Timur, \\ yatimakhusnul@yahoo.co.id
}

Korespondensi Penulis: Ruwaidah

\begin{abstract}
Abstrak: Latar belakang penelitian ini adalah untuk mengetahui bagaimana implementasi pelaksanaan kegiatan arisan di Desa Pandan Lagan, mengetahui bagaimana kontribusi arisan uang dalam menambah kesejahteraan keluarga dan bagaimana tinjauan perspektif ekonomi islam terhadap kegiatan arisan di Desa Pandan Lagan. Jenis penelitian yang digunakan yaitu penelitian lapangan. Menggunakan pendekatan deskriptif kualitatif dan teknik pengumpulan data yang digunakan observasi, wawancara dan dokumentasi. pelaksanaan kegiatan arisan yang berada di Desa Pandan Lagan cukup baik dan pada saat pengundian dilaksanakan tanpa adanya kendala atau pun masalah. Arisan ini memberikan pengaruh terhadap peningkatan kesejahteraan keluarga, karena dana yang diperoleh dari kegiatan arisan tersebut dapat digunakan untuk berbagai keperluan, baik yang bersifat konsumtif maupun produktif. Di dalam sistem arisan yang berkembang dimasyarakat, baik itu arisan uang maupun barang diperbolehkan dalam Islam. Sebab dalam arisan tidak ada unsur penipuan (tadlis).
\end{abstract}

Kata Kunci: Kontribusi Arisan, Kesejahteraan Keluarga, Ekonomi Islam.

\section{PENDAHULUAN}

Kebutuhan manusia berkembang sesuai dengan pertumbuhan dimasa globalisasi ini, seperti terdapatnya kegiatan arisan yang sudah berkembang pada saat ini. Arisan selaku lembaga keuangan yang sudah membudaya dalam masyarakat mempunyai sebagian kelebihan. Kelebihannya antara lain ialah dilihat dari aspek ekonomi serta sosial. Aspek ekonomi akan membantu masyarakat, peserta arisan mendapatkan dana yang besar, yang dengan dana itu bisa menaikkan modal usaha memulai usaha ataupun membeli sesuatu barang yang bisa jadi susah dibeli bila hanya mengandalkan pendapatan keluarga. Aspek sosial dapat terjalin hubungan yang baik antara masyarakat, profesi dan organisasi (Rusli agus, 2011). 
Arisan terdiri dari ketua yang menjadi koordinator serta anggota. Didalam sistem arisan yang berkembang dimasyarakat, baik itu arisan uang maupun barang diperbolehkan dalam islam. Sebab arisan tidak ada aspek penipuan, karena dilakukan dengan adil, transparan, disaksikan oleh peserta serta tidak terdapat yang dirugikan. Sebagai sebuah alternatif yang sudah menyebar di luas diseluruh kalangan masyarakat saat ini, arisan sangat berperan bagi tambahan modal usaha, membeli barang yang harga nilainya tinggi, atau kebutuhan yang tidak bisa dibeli jika semakin hari harga barang yang semakin melambung tinggi serta merupakan solusi masyarakat agar bisa menabung sementara tanpa adanya bunga.

Seperti masyarakat Desa Pandan Lagan yang mengikuti arisan, yaitu arisan uang. Masyarakat ini yang sebagian besar bermata pencaharian petani sawit, pinang, karet maupun buruh. Kebanyakan dari petani sawit dan pinang ini biasanya yang memiliki lahan kecil mereka mengikuti arisan agar dapat memutarkan kembali hasil uang yang didapat dalam mengikuti arisan untuk membuat usaha, menabung, atau membeli sesesuatu barang yang mungkin tidak dapat dibeli dengan pendapatan hasil panen pada saat itu. dikarenakan barang yang ingin dibeli harganya sangat mahal seperti ingin merenovasi rumah, menambah modal usaha, membuka usaha membeli emas, dan berkebun. Bahkan tidak mungkin pula dengan hasil panen pada saat itu bisa langsung memiliki modal membuka usaha seperti membuka usaha menjual kue, membuka usaha menjual makanan ringan produksi rumahan yang dititipkan di toko maupun warung-warung kecil, serta membuka usaha berjualan barangbarang dengan sistem online maupun tidak. ataupun membeli barang yang harganya cukup mahal, pastinya lebih dikumpulkan terlebih dahulu. Dengan diadakannya arisan ini maka masyarakat terutama ibu-ibu dapat menyisihkan sedikit hasil pendapatan panen tersebut untuk dapat mengikuti arisan.

Berdasarkan uraian dan keterangan diatas maka penulis tertarik untuk meneliti lebih lanjut. Penelitian ini berjudul: "KONTRIBUSI ARISAN UANG DALAM MENAMBAH KESEJAHTERAAN KELUARGA MENURUT PERSPEKTIF EKONOMI ISLAM (Studi Di Desa Pandan Lagan Kecamatan Geragai)”.

Penelitian ini mengkaji tentang kontribusi arisan uang dalam menambah kesejahteraan keluarga menurut perspektif ekonomi islam. Penelitian memfokuskan kontribusi arisan uang dalam menambah kesejahteraan keluarga menurut perspektif ekonomi islam di Desa Pandan Lagan. Rumusan masalah penelitian ini yaitu bagaimana implementasi pelaksanaan kegiatan arisan, bagaimana kontribusi arisan uang didesa pandan lagan dapat menambah kesejahteraan keluarga menurut perspektif ekonomi islam. Mengacu pada rumusan masalah diatas, maka tujuan penelitian adalah untuk mengetahui implementasi pelaksanaan kegiatan arisan, mengetahui kontribusi arisan uang dalam menambah kesejahteraan keluarga menurut perspektif ekonomi islam. 


\section{KAJIAN PUSTAKA}

Beberapa hasil penelitian yang relevan dengan penelitian ini, antara lain:

1. Irma Prihantari (2010) "TINJAUAN HUKUM ISLAM TERHADAP PELAKSANAAN ARISAN SEPEDA MOTOR "PEGUYUBAN AGUNG REZEKI" DI KECAMATAN SENTOLO KABUPATEN KULON PROGO" Arisan yang dilakukan masyarakat ini merupakan arisan motor yang dalam hukum islam dikategorikan dalam bentuk sewa beli atau kredit. Dalam pelaksanaan arisan ini digunakan sistem lelang, maka siapa saja yang bisa melakukan penawaran dengan harga tertinggi maka dialah yang akan mendapatkan motor tersebut. Menurut penelitian ini, arisan yang dilakukan dengan sistem lelang tidaklah sesuai dengan hukum islam karena dalam proses pelelangan terdapat pihak yang merasa dirugikan.

2. Rusli Agus, (2011) "KONTRIBUSI ARISAN DALAM MENAMBAH KESEJAHTERAAN KELUARGA MENURUT PERSPEKTIF EKONOMI ISLAM (STUDI DI KECAMATAN BANGKINANG BARAT)" Arisan yang dilakukan oleh masyarakat di Kecamatan Bangkinang Barat dapat memberikan pengaruh terhadap peningkatan kesejahteraan keluarga. Sehingga kegiatan arisan ini dinilai mempunyai kontribusi yang lumayan besar dalam menambah kesejahteraan keluarga tersebut. Hal ini karena dana yang diperoleh dari kegiatan arisan tersebut bisa digunakan untuk bermacam-macam keperluan, baik yang bersifat konsumtif ataupun produktif. Kegiatan arisan di Kecamatan Bangkinang Barat ialah salah satu kegiatan ekonomi rakyat yang melembaga serta merakyat. Didalam sistem arisan yang tumbuh dimasyarakat, baik itu arisan uang ataupun barang diperbolehkan dalam islam. Karena arisan tidak terdapat faktor penipuan, karena dilakukan dengan adil, transparan, disaksikan oleh peserta serta tidak terdapat yang dirugikan.

\section{Kontribusi}

Kontribusi berasal dari inggris yaitu contribute, contribution, artinya ialah keikutsertaan, keterlibatan, melibatkan diri, maupun sumbangan. Dalam hal ini kontribusi merupakan sebagai keterlibatan suatu faktor yang memberikan sumbangan terhadap hasil yang akan dicapai. Sebagai sesuatu yang memberikan sumbangan, maka kontribusi dalam hal ini dapat memberikan dampak positif maupun negatif terhadap hasil yang akan dicapai. Kontribusi positif yaitu sumbangan yang memberikan sebuah kemajuan atau peningkatan dalam mencapai suatu hasil yang diinginkan dengan tujuan tertentu (Candra wicaksono, 2017).

\section{Arisan}

Arisan adalah salah satu bentuk muamalah yang pasti dari kita mengenalnya, walaupun dari arisan bermacam-macam. Arisan itu sendiri adalah kelompok orang yang mengumpul uang secara teratur pada tiap-tiap periode tertentu. Setelah uang terkumpul, salah satu dari anggota kelompok arisan keluar sebagai pemenang. Penentuan pemenang biasanya dilakukan dengan jalan pengundian (WJS. Poerwadarminta, 2003). Sebelum melaksanakan pengundian besar jumlah uang yang di undikan sangatlah penting karena uang arisan yang akan ditarik perminggu atau perbulan. Setelah itu kesepakatan waktu pengundian atau 
pengocokan arisan itu dilakukan kapan, dimana, pengocokan arisan dilaksanakan apakah perminggu atau perbulan tergantung kesepakatan para anggota arisan tersebut.

Lottery (Inggris) artinya undian. Dengan demikian, lotere atau undian pada hakikatnya memiliki pengertian yang sama. Tetapi pengertian yang berkembang dalam masyarakat sangat berbeda. Lotere dipandang judi, sedangkan undian tidak. Karena terdapat perbedaan pendapat mengenai ketentuan hukum lotere (undian) itu, apakah termasuk judi atau tidak, maka lebih dahulu dipahami mengenai pengertian judi (maisir). Judi (maisir) merupakan permainan yang mengandung unsur taruhan, dilakukan dua orang atau lebih secara langsung atau berhadap-hadapan dalam satu majelis (M. Ali Hasan, 1997).

Sebagai kegiatan sosial, arisan digunakan sebagai media untuk saling kunjung, saling kenal, saling memberi dan membutuhkan, serta sebagai media kerukunan. Sedangkan sebagai kegiatan ekonomi, arisan merupakan institusi insidentil konsidial yang pada prinsipnya arisan adalah utang-piutang yang berfungsi sebagai tempat simpan meminjam. Dilihat dari segi keuangan, arisan tidak mempunyai keuntungan. maksudnya, uang yang kita tabung sepanjang satu putaran sama saja dengan yang kita peroleh. Bedanya hanya terletak pada perolehan arisan yang didapatkan oleh peserta di awal periode ialah semacam memperoleh pinjaman serta dapat dicicil tanpa bunga. Akan tetapi jika kita memperoleh diakhir, kita seperti menabung tanpa dapat bunga atau bagi hasil. Bila diamati dari segi sosiologis, Arisan dijadikan sebagai sarana berkumpulnya masyarakat dalam aktivitas tabarru'(tolongmenolong) meskipun pada kesimpulannya akan ada pengembalian yang sama. Hal ini bisa dikenal dengan adanya fungsi arisan ialah sebagai sarana aktivitas utang-piutang. Tidak hanya itu, arisan biasanya dibentuk untuk mempererat tali persaudaraan diantara sesama dengan dilakukannya perkumpulan antar sesama peserta arisan (Besse Armadayanti, 2017).

Ada beberapa manfaat arisan yaitu belajar menabung, sarana untuk bersosialisasi, ada kesempatan belajar dan berbisnis, menghilangkan rasa jenuh, belajar berkomitmen, dan membangun kesatuan.

\section{Pengertian Kesejahteraan Keluarga}

Pengertian kesejahteraan keluarga dalam UU no. 10 tahun 1992 ialah keluarga yang dibentuk dalam perkawinan yang sah, mampu memenuhi kebutuhan material yang layak, bertakwa kepada Tuhan yang Maha Esa, Memiliki hubungan yang selaras dan seimbang antar anggota keluarga dan masyarakat dan lingkungan. Tujuan dari pembangunan keluarga sejahtera adalah untuk mengembangkan kualitas keluarga agar dapat tumbuh rasa aman, tentram dan harapan masa depan yang lebih baik dalam mewujudkan kesejahteraan lahir dan batin (Anwar Fauzi Simamora, 2018). Tingkat kesejahteraan suatu keluarga dapat diketahui dengan kemampuannya dalam memenuhi kebutuhan hidup mereka. Semakin seseorang mampu memenuhi beragam kebutuhan hidupnya maka mereka sendiri semakin sejahtera.

\section{Pandangan Islam Mengenai Kegiatan Arisan}

Hal yang perlu diterapkan dari arisan adalah nilai keadilan, yaitu masing-masing anggota mendapatkan kesempatan dan fasilitas yang sama untuk mendapatkan undian dan 
masing-masing harus sama jumlah pembayarannya. Hukum kegiatan arisan secara konsep adalah mubah. Hal ini dikarenakan kesepakatan bersama, tidak mengandung unsur riba dan kedudukan semua orang memiliki hak yang sama. Secara mekanisme arisan juga mubah karena dalam proses pengundiannya bersifat setara dan tidak merugikan pihak tertentu.

Biasanya sistem arisan yang berlaku ditengah masyarakat ialah sistem yang dibenarkan oleh syariat islam. Selama tidak ada hal-hal yang mengandung penipuan, pengkhianatan, gharar, dan riba. Hukumnya halal dan tetap akan halal selama tidak ada pelanggaran dan penyelewenangan dan hukum baru akan berubah haram ketika manakala hal-hal tersebut terjadi.

\section{METODE PENELITIAN}

Penelitian ini menggunakan metode kualitatif dengan pendekatan deskriptif kualitatif. Pendekatan kualitatif yaitu penelitian yang menghasilkan penemuan-penemuan yang tidak dapat dicapai (diperoleh) dengan menggunakan prosedur-prosedur statistik atau cara-cara lain dari kuantifikasi (pengukuran) (Jusuf Soewadji, 2012). Dalam penelitian ini, peneliti lebih menjelaskan tentang Kontribusi arisan arisan uang dalam menambah kesejahteraan keluarga di Desa Pandan Lagan. Penelitian ini termasuk penelitian lapangan (field research), penelitian lapangan ialah menguraikan serta menggambarkan kondisi dan fenomena yang jelas menimpa suasana yang terjalin. Penelitian ini digunakan dengan menggali data yang bersumber dari lokasi atau lapangan. Selain itu penelitian ini juga menggunakan penelitian perpustakaan (library research). Partisipan dalam penelitian ini adalah masyarakat yang mengikuti kegiatan arisan dan tempat penelitian berada di Desa Pandan Lagan. Metode pengumpulan data yang penulis lakukan adalah:

\section{Observasi}

Observasi ialah pengamatan dan pencatatan dengan sistematik fenomena-fenomena yang diselidiki. Observasi ini bertujuan untuk mendapatkan data yang diperoleh dari arisan dan pemahaman serta pembuktian secara langsung dari kegiatan arisan yang ada di Desa Pandan Lagan.

\section{Wawancara}

Wawancara merupakan salah satu instrumen yang dipakai untuk menggali data secara lisan. Hal ini haruslah dicoba secara mendalam supaya kita memperoleh data yang valid dan detail (Wiratna Sujarweni, 2019). Adapun informan yang dijadikan objek dalam wawancara yaitu masyarakat yang mengikuti kegiatan arisan. Hasil wawancara tersebut diharapkan dapat memberikan dukungan data yang lengkap dan akurat.

\section{Dokumentasi}

Metode ini digunakan sebagai pelengkap guna memperoleh data sebagai bahan informasi. Dalam penelitian ini peneliti mencari sumber data dokumentasi yang sesuai dengan topik yang diteliti yaitu tentang Arisan. Metode ini hanya dijadikan sebagai bahan pelengkap saja. 
Adapun Analisis data yang akan digunakan dalam penulisan ini yaitu deskriptif kualitatif. Setelah data terkumpul oleh peneliti, peneliti butuh memastikan keabsahan data yang terkumpul supaya hasil yang didapat lebih pas dan akurat. Penemuan ataupun data dapat dikatakan valid apabila tidak terdapat perbandingan antara yang dilaporkan peneliti dengan apa yang sebetulnya terjalin pada objek penelitian (Sugiyono, 2011). Namun, butuh diketahui bahwa kebenaran realitas data menurut peneliti kualitatif tidak bersifat tunggal, namun jamak serta tergantung pada konstruksi manusia, dibangun dalam diri seseorang selaku hasil proses mental masing-masing orang dengan bermacam latar belakangnya.

\section{HASIL DAN PEMBAHASAN}

\section{Implementasi pelaksanaan kegiatan arisan di Desa Pandan Lagan}

Arisan uang yang diadakan oleh para anggota arisan dilaksanakan seperti arisanarisan pada umumnya dengan menyetorkan sejumlah uang yang telah ditentukan, dalam setiap waktu yang telah ditentukan pula. Setiap bulannya anggota arisan berkumpul guna menghitung jumlah uang yang berhasil dikumpulkan. Setelah diketahui, bahwa uang yang berhasil dikumpulkan sudah terkumpul dengan jumlah yang ditentukan maka dilakukan dengan undian untuk mengetahui siapa yang berhak mendapatkan arisan tersebut dengan kesepakatan anggota lainnya jika telah disepakati bersama maka nama yang keluar undian lah yang berhak menerima arisan itu. Selanjutnya pada tiap bulan dilakukan pengundian arisan uang secara berangsur-angsur, sehingga seluruh anggota mendapatkan giliran arisan tersebut sampai dengan selesai. Pelaksanaan kegiatan arisan sesuai dengan tata tertib yang ada, tidak ada kendala atau masalah hanya saja masih ada peserta arisan yang melakukan pembayaran melewati jatuh tempo tanggal pembayaran.

\section{Kontribusi Arisan Uang Dalam Menambah Kesejahteraan Keluarga}

Kegiatan arisan yang dilakukan di Desa Pandan Lagan dapat memberikan kontribusi dalam menambah kesejahteraan keluarga diambil dari beberapa hasil wawancara yang peneliti lakukan. Hal ini karena dana yang diperoleh dari arisan tersebut dapat digunakan untuk berbagai keperluan yang bersifat konsumtif maupun produktif. Seperti dapat digunakan untuk merenovasi rumah, berdagang, biaya membayar anak sekolah, membeli barang atau perhiasan, pesta perkawinan, dan membeli bibit untuk berkebun. Di samping itu uang arisan akan membantu peserta arisan mendapatkan dana yang besar, yang dana itu dapat untuk menambah modal usaha, memulai usaha, dan atau membeli barang yang mungkin sulit dibeli jika hanya mengandalkan pendapatan keluarga pada saat itu. bahwa seluruh peserta arisan menggunakan dana arisan yang diterimanya untuk menambah modal atau mengembangkan usahanya. Kemudian dana arisan ini sifatnya hanya menambah sehingga bagi para pedagang, memanfaatkan dana arisan untuk menambah modal usaha sangat berarti untuk diolah kembali agar mendapatkan keuntungan. Sebagai sebuah alternatif yang telah menyebar luas dikalangan masyarakat khususnya pedagang.

Harapan bagi para peserta arisan yang membuat usaha menjadi sesuatu harapan yang harus terwujud dalam kegiatan usaha, salah satu harapan yang di inginkan pedagang yaitu harapan untuk hidup sejahtera dan mendapatkan modal usaha. Harapan lainnya yaitu 
pedagang mengandalkan dengan mengikuti kegiatan arisan, bisa sangat membantu untuk memenuhi kebutuhan hidupnya dan menambahkan modal usahanya.

\section{Tinjauan Perspektif Ekonomi Islam Terhadap Pelaksanaan Kegiatan Arisan Di Desa Pandan Lagan}

Arisan ialah bentuk tolong menolong saling bantu membantu satu sama lain yang praktis tidak memberatkan dan semua diuntungkan. Arisan merupakan salah satu alternatif bagi masyarakat yang ingin menabung dalam waktu yang singkat. Arisan yang diperbolehkan adalah bila memenuhi kriteria berikut:

- Seluruh peserta arisan yang melakukannya dengan niat yang baik dan tulus tidak ada unsur kerelaan bukan paksaan sehingga tidak mungkin menunggak dari kewajibannya ketika sudah pernah mendapatkan arisan (menang).

- Tidak boleh dilakukan praktek-praktek ribawi, penipuan, penggelapan, dan hal-hal yang dilarang dalam islam.

- Mempunyai nilai positif seperti untuk mempererat silaturahmi dan persaudaraan diantara peserta arisan atau forum komunikasi yang sangat bermanfaat.

- Arisan yang dilakukan harus mengacu pada etika dan akhlak islam, juga bukan sekedar berhura-hura dan menghamburkan uang atau sekedar pamer perhiasan dan lain sebagainya. Juga harus dihindari semua termasuk perbuatan yang dilarang seperti ghibah (membicarakan aib orang lain), fitnah, dengki, dan riya'.

- Bila terjadi perselisihan dalam pengelolaan arisan harus diselesaikan dengan cara yang sebaik-baiknya tidak dengan cara yang buruk dan memutuskan hubungan silaturahmi.

Arisan yang dilakukan oleh masyarakat Desa Pandan Lagan dilakukan tanpa unsur paksaan, sukarela, dengan penuh tanggung jawab untuk membayar dan melunasi setiap pembayaran yang dilakukan perbulannya sampai dengan selesai. Disamping itu arisan juga mengandung unsur saling bantu membantu atau tolong menolong hal ini sejalan dengan QS. Thaha: 29-32 yang menjelaskan bahwa manusia dianjurkan untuk selalu saling bantu membantu satu sama lain dalam hal kebaikan. Begitu pula halnya dalam kegiatan arisan dimana maslahah atau kebaikan lebih besar dibandingkan unsur mudharatnya. Selain itu di dalam arisan tidak mengandung taghrir (gharar) yakni bahaya, resiko dan ketidakpastian. Yang dimaksud taghrir ialah melakukan sesuatu secara membabi buta tanpa pengetahuan yang mencukupi, atau mengambil resiko tanpa mengetahui dengan jelas apa akibatnya. Dilihat dari pengertian taghrir arisan ini jelas tidak termasuk didalamnya, karena dalam arisan ini seluruh peserta arisan telah mengetahui dengan pasti mekanisme dan proses arisan, dan dengan sistem undian pun peserta sudah mengetahui jika keinginan untuk mendapatkan arisan belum tentu terpenuhi, tetapi suatu saat nanti pasti akan memperolehnya.

Arisan tidak dilarang dalam islam, dengan catatan tidak ada unsur paksaan, gharar, tadlis, dan bermanfaat bagi seluruh anggota arisan, ada unsur tolong menolong dan dilakukan secara adil dan transparan. Namun jika pelaksanaan arisan ternyata terdapat unsur gharar dan tadlis, maka kebolehan tersebut sangat dilarang. Kegiatan arisan yang dilakukan masyarakat di Desa Pandan Lagan sama sekali tidak ada mengandung unsur judi, penipuan, pemerasaan 
atau untung-untungan bahkan merugikan para peserta yasinan. Karena pada akhirnya semua uang akan kembali kepada pemiliknya tidak ada satu pun tidak yang diuntungkan atau dirugikan. Kalaupun menang arisan sebenarnya itu adalah tidak menang, hanya saja sedang mendapat giliran menerima uang arisan. Pada kesempatan arisan selanjutnya, orang inilah yang mendapatkan arisan secara bergiliran sesuai undian dan menerima uang arisan.. kegiatan arisan yang dilakukan oleh masyarakat Desa Pandan Lagan merupakan salah satu sarana sosial bermasyarakat yang dapat membantu kebutuhan satu sama lain.

\section{KESIMPULAN DAN SARAN}

Berdasarkan hasil penelitian maka dapat disimpulkan bahwa: Implementasi pelaksanaan kegiatan arisan di Desa Pandan Lagan dilaksanakan dengan cukup baik sesuai dengan tata tertib yang telah dibuat dan disepakati sebelum mengikuti arisan tersebut. Kendala atau masalah yang terjadi hanya pada saat pembayaran yang pembayarannya sering lebih dari tanggal jatuh tempo pembayaran. Arisan yang dilakukan oleh masyarakat desa Pandan Lagan dapat menambah kesejahteraan keluarga dan kontribusi yang cukup. Hal ini karena dana yang digunakan untuk berbgai keperluan terutama untuk menambah modal usaha yang dana tersebut akan diolah kembali agar mendapat keuntungan. Kegiatan arisan di desa Pandan Lagan diperbolehkan dalam islam, karena dalam arisan yang dilakukan tidak ada unsur riba, penipuan (tadlis), karena dilakukan dengan adil, transparan disaksikan oleh peserta dan tidak ada yang dirugikan.

\section{DAFTAR RUJUKAN}

Agus, rusli. (2011). "Kontribusi arisan dalam menambah kesejahteraan keluarga menurut perspektif ekonomi (studi di kecamatan bangkinang barat)" . Riau.

Anto, Besse armadayanti. (2017). "Kontribusi arisan mingguan para pedagang dipasar belopa kabupaten luwu dalam menambah modal usaha (tinjauan ekonomi islam)”. Makassar.

Fauzi simamora, Anwar. (2018) "peranan usaha mikro pisang pasir dalam meningkatkan kesejahteraan keluarga”. SKRIPSI.UIN sumatera utara. Medan.

Hasan ali, A.M. (2004). Asuransi dalam perspektif hukum islam: Suatu tinjauan analisis Historis, Teoritis dan Praktis. Cet ke-2.Jakarta: Kencana.

Poerwadarminta, WJS. (2003). Kamus Umum Bahasa Indonesia. Jakarta: Balai Pustaka. Soewadji, Jusuf. (2012). pengantar metodologi penelitian, jakarta:mitra wacana media Sugiyono. (2012). memahami penelitian kualitatif. Bandung: Alfabeta.

Sujarweni, Wiratna. (2019). metodologi penelitian bisnis dan ekonomi. Yogyakarta: Pustakabarupress.

Wicaksono, Candra. (2017). "kontribusi motivasi belajar,lingkungan belajar dan kebiasaan belajar terhadap prestasi belajar siswa teknik kendaraan ringan SMK muhammadiyah 1 salam, magelang”. Universitas negeri Yogyakarta. Yogyakarta 